\title{
Paracetamol, alcohol and the liver
}

\author{
Laurie F. Prescott
}

Emeritus Professor of Clinical Pharmacology, University of Edinburgh

It is claimed that chronic alcoholics are at increased risk of paracetamol (acetaminophen) hepatotoxicity not only following overdosage but also with its therapeutic use. Increased susceptibility is supposed to be due to induction of liver microsomal enzymes by ethanol with increased formation of the toxic metabolite of paracetamol. However, the clinical evidence in support of these claims is anecdotal and the same liver damage after overdosage occurs in patients who are not chronic alcoholics. Many alcoholic patients reported to have liver damage after taking paracetamol with 'therapeutic intent' had clearly taken substantial overdoses. No proper clinical studies have been carried out to investigate the alleged paracetamolalcohol interaction and acute liver damage has never been produced by therapeutic doses of paracetamol given as a challenge to a chronic alcoholic.

The paracetamol-alcohol interaction is complex; acute and chronic ethanol have opposite effects. In animals, chronic ethanol causes induction of hepatic microsomal enzymes and increases paracetamol hepatotoxicity as expected (ethanol primarily induces CYP2E1 and this isoform is important in the oxidative metabolism of paracetamol). However, in man, chronic alcohol ingestion causes only modest (about twofold) and short-lived induction of CYP2E1, and there is no corresponding increase (as claimed) in the toxic metabolic activation of paracetamol. The paracetamol-ethanol interaction is not specific for any one isoform of cytochrome P450, and it seems that isoenzymes other than CYP2E1 are primarily responsible for the oxidative metabolism of paracetamol in man. Acute ethanol inhibits the microsomal oxidation of paracetamol both in animals and man. This protects against liver damage in animals and there is evidence that it also does so in man. The protective effect disappears when ethanol is eliminated and the relative timing of ethanol and paracetamol intake is critical.

In many of the reports where it is alleged that paracetamol hepatotoxicity was enhanced in chronic alcoholics, the reverse should have been the case because alcohol was actually taken at the same time as the paracetamol. Chronic alcoholics are likely to be most vulnerable to the toxic effects of paracetamol during the first few days of withdrawal but maximum therapeutic doses given at this time have no adverse effect on liver function tests. Although the possibility remains that chronic consumption of alcohol does increase the risk of paracetamol hepatotoxicity in man (perhaps by impairing glutathione synthesis), there is insufficient evidence to support the alleged major toxic interaction. It is astonishing that clinicians and others have unquestioningly accepted this supposed interaction in man for so long with such scant regard for scientific objectivity.

Keywords: CYP2E1, cytochrome P450, ethanol, hepatotoxicity, interaction, isoenzymes, overdose, paracetamol, therapeutic misadventure, therapeutic use

Correspondence: Professor L. F. Prescott, 24 Colinton Road, Edinburgh EHIO 5EQ.

Received 16 April 1999, accepted 16 December 1999. 


\section{Introduction}

There have been many reports claiming that the hepatotoxicity of paracetamol (acetaminophen) is increased in chronic alcoholics, and that such individuals not only carry an increased risk of severe and fatal liver damage after acute overdosage [1-20], but that similar serious liver damage may also occur with 'therapeutic' use $[5,9,10,17,18,21-64]$. In the original studies of the mechanisms of toxicity, paracetamol was found to cause liver damage through conversion by hepatic cytochrome P450 enzymes to a minor but toxic intermediate metabolite [65-68] and this was subsequently identified as $N$-acetyl-p-benzoquinoneimine $[69,70]$. In accordance with this mechanism, the susceptibility to paracetamolinduced liver damage in animals was increased when these enzymes were stimulated by prior administration of inducing agents such as phenobarbitone and 3-methylcholanthrene, and decreased by inhibitors such as piperonyl butoxide and 4-methylpyrazole [65, 66, 71]. Chronic administration of ethanol also causes microsomal enzyme induction in animals and as expected, this increased the metabolic activation and the hepatotoxicity of paracetamol [26, 72-89]. In the circumstances, it was natural to suspect that there might be similar potentiation of paracetamol hepatotoxicity following overdosage in chronic alcoholics and indeed, this had been suggested in an early study in which the outcome of severe paracetamol poisoning in potentially induced patients appeared to be worse than in similar noninduced patients [1]. Subsequently, many anecdotal reports appeared describing severe and sometimes fatal liver damage in chronic alcoholics taking paracetamol in overdosage [2-20], as well as after its use for therapeutic purposes $[5,9,10,17$, 18, 21-64].

The collective weight of these uncontrolled case reports has been taken uncritically as 'proof' that the hepatotoxicity of paracetamol is increased in chronic alcoholics and it is universally assumed that as in animals, the mechanism is increased production of the toxic metabolite caused by induction of hepatic drug metabolizing enzymes. These beliefs were strengthened further by the demonstration in animals that the primary isoform of cytochrome P450 which is induced by ethanol (CYP2E1) is also involved in the metabolic activation of paracetamol [90-102]. Potentiation of paracetamol hepatotoxicity by chronic consumption of ethanol in man is now accepted as established truth and it has been referred to as a 'classic syndrome of medicine' [60]. As this review will show, however, there is insufficient evidence to justify the claims made for such an interaction in man.

\section{Clinical studies}

Paracetamol overdose

However convincing the numerous reports of liver damage following paracetamol overdosage in chronic alcoholics may be [2-20], they are purely anecdotal and the inescapable fact remains that exactly the same severe and fatal liver damage occurs after overdosage in patients who are not chronic alcoholics. The doses claimed to have been taken by the chronic alcoholics ranged from less than $10 \mathrm{~g}[6,17,18,103]$ to more than $30 \mathrm{~g}[5,10,15,18,20$, 104, 105]. Apart from the presence of underlying chronic liver disease in some patients, there is no difference in the clinical course of paracetamol poisoning in alcoholics. However, alcoholics may appear to be more susceptible to the hepatotoxicity of paracetamol because they often present late. Patients who present late are more severely poisoned and have a much worse prognosis than those who come to hospital early, regardless of alcohol intake [106-109]. In addition, the apparent association of severe liver damage and excessive alcohol intake largely reflects a population which is likely to take overdoses [108]. These are important sources of bias that exaggerate the belief that chronic alcoholics suffer more severe liver damage following an overdose of paracetamol.

There have been no proper prospective controlled studies in which the outcome of paracetamol poisoning has been compared in chronic alcoholics and similarly poisoned nonalcoholic patients. In the original study in which it was suggested that enzyme-induced patients are at greater risk of severe liver damage [1], only three of the eight potentially induced patients were chronic alcoholics and it is impossible to draw any conclusion with such small numbers. In a study of selected patients with paracetamol poisoning who had been referred to a specialist liver unit, the prognosis was said to be worse in patients who consumed more than the maximum recommended amount of alcohol compared with that in those who drank less [110]. However, alcohol intake was determined retrospectively from case notes, and this information was missing in an unstated number of patients. In addition, the patients with excessive alcohol intake had taken larger doses of paracetamol. In other reports from the same unit, it was not possible to show that the outcome was worse in patients with previous excessive intake of alcohol [106, 108]. In other large-scale studies of paracetamol poisoning, the severity of liver damage and the prognosis were not adversely affected by alcoholism [111-114]. A more recent report indicated that liver damage following paracetamol overdose, as shown by aminotransferase activity, was greater in at risk patients with chronic use of ethanol than in those without. Chronic ethanol did not increase liver toxicity among low risk cases [115]. Other investigators 
have suggested that potentiation of paracetamol hepatotoxicity in such patients was due not so much to the effects of the alcohol as to poor diet and fasting [17]. Fasting increases paracetamol hepatotoxicity in rats by decreasing glucuronide and sulphate conjugation so that the proportion converted to the toxic metabolite is significantly enhanced [116]. A similar mechanism has never been demonstrated in man.

Overall, there is no consistent clinical evidence that chronic alcoholics are at significantly increased risk of liver damage, or that they have a uniformly worse prognosis following an overdose of paracetamol. If this were the case, many chronic alcoholics would develop severe liver damage at normally nontoxic plasma paracetamol concentrations, below the standard treatment line. In fact, there have only been isolated reports of such cases $[13,16$, $20,117]$.

\section{Use of paracetamol with 'therapeutic intent' - 'therapeutic misadventure'}

Many of the patients involved in the numerous anecdotal case reports of severe and sometimes fatal liver damage following the apparently innocent use of paracetamol with 'therapeutic intent' have been chronic alcoholics [5, 9, 10, 17, 18, 21-64]. At first sight, it seems that most of these unfortunate patients had taken normal, or little more than normal doses of paracetamol for short periods because of symptoms such as pain, and that there were no warning signs before the onset of liver damage. However, the clinical picture on presentation was invariably typical of an acute overdose taken 3 or 4 days previously with the maximum elevation of aminotransferases usually occurring on the day of admission followed by a rapid return to normal. Such a pattern would not be seen if, as often claimed, the drug had been taken regularly over a period of several days up to the time of admission. As might be expected following acute overdosage, some patients developed renal failure and some died in hepatic failure $[4,5,8,22,23,26,33,34,37,40,48]$. In many of the chronic alcoholic patients it is clear from the history [10, 17, 18, 21, 27, 29, 33, 39, 49, 60] and from plasma paracetamol measurements (when available) [24, 32, 37, 40], that major overdoses had been taken. It seems that in their haste to draw attention to the perceived dangers of paracetamol, many authors have failed to distinguish between a 'therapeutic dose' and 'therapeutic intent', and a maximum single dose $(1 \mathrm{~g})$ and a maximum divided daily dose $(4 \mathrm{~g})$. Similarly, gross overdosage such as ingestion of $10-25 \mathrm{~g}$ daily can hardly be described as 'therapeutic misadventure' [17, 18, 21, 26, 27, 29, 33, 39, 49, 60]. The volume of these reports has been increased by reporting the same patients more than once $[9,10,25,26,39,60$, 118 , and by endlessly repeated reviews of published cases
$[39,41,47,58,60,62,119,120]$. It should also be noted that the two largest and most recent reviews were supported financially by companies producing analgesics which compete with paracetamol $[58,60]$. The presumed toxic interaction between paracetamol and alcohol has also been the subject of scores of uncritical and often poorly informed comments and editorials.

It is very difficult to accept that single and repeated daily doses of as little as 1-3 g paracetamol could cause severe and fatal liver damage in alcoholics as claimed [9, 24, 25, $30,32,37,39,40,42,46,51,52,55,60]$. In one report, 67 cases of 'therapeutic misadventure' in chronic alcoholics were solicited by word of mouth or letter from colleagues and 27 allegedly took less than $4 \mathrm{~g}$ paracetamol daily [60]. The drug history must always be suspect in chronic alcoholics. Some $5-8 \%$ of a therapeutic dose of paracetamol is normally converted to the toxic metabolite and according to the hepatic content of glutathione, the theoretical single hepatotoxic dose in an adult is normally about $15 \mathrm{~g}$ [121]. This agrees well with the threshold dose of $150-250 \mathrm{mg} \mathrm{kg}^{-1}$ observed in poisoned patients [122]. Even if the whole of a therapeutic dose were converted to the toxic metabolite in the patients mentioned above, it could hardly be sufficient to produce any degree of liver damage let alone fatal hepatic failure.

In the absence of control data these anecdotal case reports in themselves cannot 'prove' that therapeutic doses of paracetamol cause liver injury in chronic alcoholics. The fact that there are similar (but sometimes equally suspect) reports of patients who were not chronic alcoholics [7, 18, 40, 41, 58, 103, 123-127] is conveniently overlooked. Indeed, if paracetamol in normal doses is as dangerous in chronic alcoholics as it is claimed, liver damage should be commonplace considering the enormous scale on which the drug is used and the prevalence of alcoholism. In one survey, nearly a third of chronic alcoholics admitted to taking paracetamol regularly and reports of abuse were frequent with almost 5\% fitting the patterns of drinking and use that are theoretically associated with hepatotoxicity [120]. Where are all these patients? Some alcoholics can be extraordinarily resistant to paracetamol and one such individual apparently took 15-25 g paracetamol daily for 5 years without evidence of liver toxicity [128]. Finally, and most importantly, there has never been a single documented instance of any degree of acute liver damage produced by therapeutic doses of paracetamol given as a challenge in any chronic alcoholic under properly controlled conditions. If paracetamol is as dangerous in the chronic alcoholic as claimed by so many investigators, why has no such example been published? It is accepted that proper challenge studies in chronic alcoholics are not easy but there should be no great risk with the supervised administration of appropriately graded doses of paracetamol. 


\section{Acute vs chronic ethanol}

The position is complicated enormously because acute and chronic consumption of ethanol can have opposite effects on paracetamol hepatotoxicity. When a single dose of ethanol is given at or about the same time as paracetamol, it protects animals against hepatotoxicity even if they have been sensitized by previous chronic administration of alcohol [71, 78, 81, 85, 129-134]. This protective effect is associated with inhibition of the toxic metabolic activation of paracetamol both in vivo $[79,82,134-136]$ and in vitro $[136,137]$. Ethanol protects at concentrations as low as $2 \mathrm{~mm}$ [137] but once it has disappeared from the system, paracetamol metabolism reverts to the previous state. With acute ingestion, the timing in relation to the taking of the paracetamol is critical $[71,76,83,85,131,138]$ and in certain circumstances the effects of acute and chronic ethanol tend to cancel out $[79,102]$. The protective effect of a single dose of ethanol decreases progressively as the time interval between the administration of ethanol and paracetamol increases. In mice, protection is lost after $6 \mathrm{~h}$ [85] and toxicity is greatly increased after a delay of 16$18 \mathrm{~h}$, presumably as a result of enzyme induction $[83,138]$. The effect of ethanol on the metabolic activation of paracetamol is generally thought to be caused by competitive inhibition. However, it seems to produce less inhibition in vitro than in vivo, and an alternative mechanism based on the depletion of cytosolic NADPH has been proposed $[71,136]$.

In contrast, the chronic administration of ethanol increases the hepatotoxicity and lethality of paracetamol in animals provided that sufficient time is allowed for the elimination of the ethanol after the last dose $[26,72,74-$ $78,80-83,85-89,133,139-142]$. This effect is usually associated with microsomal enzyme induction with enhanced metabolic activation of paracetamol as shown by increased production of its glutathione-derived conjugates $[73,78,79,84,86]$. However, there have been some anomalous findings. Thus chronic ethanol did not always cause induction [76, 81, 82, 143], and hamsters treated with chronic ethanol and then withdrawn from it for $24 \mathrm{~h}$ were more resistant to the toxicity of paracetamol than control animals not exposed to ethanol [76]. Nevertheless, the potentiation of the hepatotoxicity of paracetamol by chronic ethanol intake in animals forms the mainstay of the belief that there is similar enhancement of toxicity in chronic alcoholics.

In man, acute ethanol has exactly the same inhibitory effect on the oxidative metabolism of paracetamol as it does in animals. Thus alcohol inhibited the toxic metabolic activation of paracetamol by human liver microsomes [71] and it produced a major reduction in the fractional urinary excretion of the cysteine and mercapturic acid conjugates of paracetamol in healthy nonalcoholic volunteers [144-147] as well as in heavy drinkers [148]. A substantial proportion of patients who take overdoses of paracetamol have also taken alcohol at the same time $[18,107,109,112,149]$ and this appears to protect them against liver damage [111, 150]. The protective action of alcohol taken at the time of an overdose probably adds significantly to the large individual variation in susceptibility to the toxicity of paracetamol.

Chronic excessive use of ethanol undoubtedly causes short-term induction of CYP2E1 in man. CYP2E1 activity was increased by a factor of two in alcoholics who were still drinking but this effect was short-lived and activity was not increased after abstinence for more than 5-10 days [151]. Incubation of primary hepatocyte cultures from three human livers with ethanol for $92 \mathrm{~h}$ also induced CYP2E1 activity but the extent of induction varied [152]. However, in another study, chronic alcoholics showed no enhancement of activity unless they had active liver damage [153]. Hydroxylation of chlorzoxazone has been used as a probe for CYP2E1 activity and the metabolic ratio was increased in chronic alcoholics although activity decreased with increasing severity of alcoholic liver disease [154, 155]. The short duration of induction of CYP2E1 by ethanol in man was confirmed in another study in which the metabolic ratio of chlorzoxazone returned to control levels in chronic alcoholics after they had abstained for 8 days [156]. Taken together, these studies indicate only modest, variable and short-lived induction of CYP2E1 by ethanol in man. The induction of CYP2E1 by ethanol in animals is dose-dependent and multiple mechanisms are involved including increased synthesis of mRNA and stabilization of the 2E1 protein $[102,157]$. With the latter mechanism there is likely to be binding of ethanol to the active site of the enzyme and this would probably cause simultaneous inhibition and induction [102].

Insufficient attention has been given to the timing of alcohol intake in relation to paracetamol consumption and toxicity in clinical reports. If the same circumstances apply in man as in animals, alcohol could increase or decrease the toxicity of paracetamol, or have no effect, depending on the timing and duration of alcohol consumption. In some reports purporting to show that chronic alcoholics are at increased risk of paracetamol hepatotoxicity, alcohol seems to have been taken acutely at or about the same time as the paracetamol $[2,4,6,11,12,18,22,23,33,35,39,48$, $53,55,59,61,63]$. In these cases, the alcohol should have reduced paracetamol toxicity rather than enhanced it as claimed!

Chronic alcoholics are likely to be at their most vulnerable during the first few days after stopping their regular drinking when the ethanol has been completely eliminated because at this time any induction would be unopposed [102, 157]. It is true that this pattern of events 
has been described in some patients who developed paracetamol-induced liver damage shortly after discontinuing their regular intake of alcohol because of illness or injury $[6,11,13,21,34,37,39,44,54]$. It follows that the definitive test to determine whether normal therapeutic doses of paracetamol could cause severe hepatic injury in chronic alcoholics would be to give it during the first few days of alcohol withdrawal. Such a study has indeed been carried out. Sixty withdrawing alcoholic inpatients were given either paracetamol $1 \mathrm{~g} 4$ times daily or placebo for 2 days with biochemical monitoring on days 2 and 4 . There were no differences between the groups in respect of hepatic and renal function [158]. In another report, routine screening for $48 \mathrm{~h}$ of 373 patients admitted to an alcohol detoxification unit failed to reveal any instance of paracetamol hepatotoxicity [159]. These negative findings make it most unlikely that chronic alcoholics are at significant risk of hepatotoxicity following the normal therapeutic use of paracetamol.

\section{Paracetamol metabolism in chronic alcoholics}

If chronic consumption of ethanol does cause induction of microsomal enzymes in man with stimulation of the metabolic activation of paracetamol and enhanced toxicity as claimed, it follows that there should be a substantial increase in the formation of glutathione-derived metabolites and a corresponding increase in the fractional urinary excretion of the cysteine and mercapturic acid conjugates. In one report, the recovery of these metabolites was increased (although remaining well within normal limits) in abstaining alcoholics without liver disease [160] and in another, chronic alcoholics in withdrawal produced more glutathione-derived metabolites of paracetamol than healthy subjects although the increase was minimal and barely of statistical significance [161]. In studies of the time course of induction and inhibition of paracetamol metabolism by ethanol, healthy volunteers were given $6 \mathrm{~h}$ infusions of ethanol or dextrose solution on two separate occasions. On the first, they received $500 \mathrm{mg}$ of paracetamol $30 \mathrm{~min}$ after the start of the infusion and on the second the same dose was taken $8 \mathrm{~h}$ after the end of the infusion. When paracetamol was taken with the ethanol infusion there was a $72 \%$ reduction in the formation of the toxic metabolite but when it was taken $8 \mathrm{~h}$ after stopping the infusion there was a modest but toxicologically insignificant increase of $24 \%$ [147]. Other investigators have failed to demonstrate any increase in the toxic metabolic activation of paracetamol in heavy drinkers [148] or in abstaining chronic alcoholics [162]. In one chronic alcoholic who apparently took $15-25 \mathrm{~g}$ paracetamol daily without liver damage, there was no evidence of increased toxic metabolic activation [128]. When chronic alcoholics were studied within $48 \mathrm{~h}$ of abstinence from alcohol and again after 15 days, there was no decrease in the $24 \mathrm{~h}$ urinary excretion of the mercapturic acid conjugate of paracetamol as would be expected had they been induced [163]. Claims that an increased clearance of paracetamol in abstaining chronic alcoholics is evidence of enhanced hepatotoxicity [164, 165] can be discounted because this would largely reflect changes in the major elimination pathway of glucuronide conjugation, and no conclusions can be drawn concerning any effects on the minor route of toxic metabolic activation. Indeed, all other things being equal, induction of glucuronide conjugation would actually reduce the risk of paracetamol hepatotoxicity. In another study, the plasma paracetamol half-life (based on very limited sampling) was not abnormal in chronic alcoholics and was not related to the different genotypes of CYP2E1 [166].

Taken together, these studies indicate that formation of the toxic metabolite of paracetamol is not increased to a toxicologically significant extent in chronic alcoholics and in this respect, the situation in man differs from that in animals. Nevertheless, it is important to recognize that chronic alcoholics are likely to be at greatest risk during withdrawal when any effect of induction on the metabolic activation of paracetamol would no longer be countered by the inhibitory effects of circulating ethanol. If chronic alcoholics really do have an increased susceptibility to the hepatotoxicity of paracetamol, then it seems that a mechanism other than induction of CYP2E1 must be responsible. In this context glutathione functions as an important defence mechanism against paracetamol hepatotoxicity and it has been suggested that chronic alcoholics could be at increased risk because of a reduced capacity for glutathione synthesis [162, 167].

\section{Isoenzyme specificity}

Much has been made of the observation that in animals the major isoform of cytochrome $\mathrm{P} 450$ induced by ethanol (CYP2E1) also plays an important role in the toxic metabolic activation of paracetamol $[17,18,49,60$, 87, 90, 92-98, 100-102, 155, 165, 166, 168] and the finding that the human isoenzyme also converted paracetamol to its potentially toxic metabolite seemed to settle the matter [58, 60, 93, 96, 97, 157, 169]. However, most of these studies were carried out in mice, rats and rabbits and in one study with human CYP2E1, activity was demonstrated at the supratoxic concentration of $1500 \mathrm{mgl}^{-1}$ [96]. Subsequent investigation at more clinically realistic concentrations indicated only a minor role for CYP2E1 and that CYP3A4 was probably more important [170]. Many isoforms of cytochrome P450 including 1A1, 1A2, 2A1, 2A6, 2B1, 2C11, 2C12, 2E1, $3 \mathrm{~A} 1$ and $3 \mathrm{~A} 4$ contribute to the metabolism of paracetamol $[95,97,169,171]$. More recent studies indicate important 
roles for CYP1A2 and CYP3A in the metabolism of ethanol and the metabolic activation and hepatotoxicity of paracetamol in animals [87-89, 99, 100, 168, 172]. In man, CYP1A2 does not seem to be quantitatively important in the metabolism of paracetamol to a toxic intermediate [173]. Because of dose dependence and species differences in the expression, activity and inducibility of these isoenzymes, it is not justifiable to extrapolate the results of animal studies to clinical conditions in man. At the end of the day, it does not matter too much which isoenzymes are responsible for the metabolism of paracetamol and ethanol in man because the toxic metabolic activation of paracetamol is not increased in chronic alcoholics. Although different isoenzymes of cytochrome P450 may be involved at different concentrations of paracetamol, it seems that the forms which are induced by ethanol are not primarily responsible for the toxic metabolic activation of paracetamol in man.

\section{Conclusions}

The interactions between paracetamol and ethanol are complex and many questions remain to be answered. In animals, chronic administration of ethanol causes microsomal enzyme induction with increased toxic metabolic activation of paracetamol and enhanced hepatotoxicity. Conversely, the acute administration of ethanol inhibits the potentially toxic oxidative metabolism of paracetamol and protects against liver damage. This protective effect disappears when the ethanol is eliminated and the time interval between the intake of ethanol and paracetamol is critical. The interactions between paracetamol and ethanol do not seem to be specific for any one isoform of cytochrome $\mathrm{P} 450$.

If the same circumstances apply in man as in animals, alcohol could increase or decrease the toxicity of paracetamol, or have no effect, depending on the timing and duration of alcohol consumption. Alcohol taken with paracetamol is likely to protect against liver toxicity and chronic alcoholics should be at their most vulnerable during the first few days of withdrawal. Clinical reports are difficult to interpret because insufficient attention has been given to the timing of alcohol intake in relation to the ingestion of paracetamol.

In contrast to the findings in animals, chronic alcoholics do not produce abnormally increased amounts of the potentially toxic metabolite of paracetamol. There is only modest, short-lived induction of CYP2E1 in chronic alcoholics and it seems that other isoenzymes are primarily responsible for the metabolic activation of paracetamol in man. In keeping with the metabolic data, there is no convincing clinical evidence to support the claims that chronic alcoholics are at increased risk of liver damage either following overdosage of paracetamol or with its therapeutic use. Such evidence as exists is purely anecdotal and similar toxicity has been reported in both circumstances in patients who are not alcoholic. Many of the patients who allegedly took paracetamol with 'therapeutic intent' had clearly taken major overdoses. Maximum therapeutic doses of paracetamol had no adverse effect on liver function in chronic alcoholics in their most susceptible state during withdrawal.

In many of the clinical reports cited, scientific discipline and the basic principles of pharmacoepidemiology have been disregarded and unsupportable conclusions have been drawn. By the same token, the authors of authoritative-sounding reviews and editorials on the subject of paracetamol and alcohol should recognize that they have a responsibility to impart the truth to their readers rather than to feed them a continuous diet of misinformation. Although the possibility that chronic alcoholics are at increased risk of paracetamol hepatotoxicity can by no means be excluded, the available evidence does not support claims for a major toxic interaction between ethanol and paracetamol in man. Further studies are required but until these issues are resolved, all patients who take alcohol in excess must continue to be considered at high risk following an overdose of paracetamol and be treated with $\mathrm{N}$-acetylcysteine accordingly.

The author consults for SmithKline Beecham Consumer Health Care, Brentford, Middlesex.

\section{References}

1 Wright N, Prescott LF. Potentiation by previous drug therapy of hepatotoxicity following paracetamol overdosage. Scot Med J 1973; 18: 56-58.

2 Scott CR, Stewart MJ. Cysteamine treatment in paracetamol overdose. Lancet 1975; i: 452-453.

3 Emby DJ, Fraser BN. Hepatotoxicity of paracetamol enhanced by ingestion of alcohol. S Afr Med J 1977; 51: 208-209.

4 Johnson MW, Friedman PA, Mitch WE. Alcoholism, nonprescription drugs and hepatotoxicity: the risk from unknown acetaminophen ingestion. Am J Gastroenterol 1981; 76: $530-533$.

5 Himmelstein DU, Woolhandler SJ, Adler RD. Elevated SGOT/SGPT ratio in alcoholic patients with acetaminophen hepatotoxicity. Am J Gastroenterol 1984; 79: 718-720.

6 Fleckenstein JL. Nyquil and acute hepatic necrosis. N Engl J Med 1985; 313: 48.

7 Yasunaga M, Matsuda S, Murata M, et al. Two cases of acute liver injury caused by ingesting small dose of acetoaminophen. Acta Hepatologica Japonica 1985; 26: 493-499.

8 Bell H, Schjonsby H, Raknerud N. Alvorlig leverskade etter inntak av paracetamol i suicidal hensikt. Tidsskr Nor Lageforen 1987; 107: 1041-1042.

9 Denison H, Kaczynski J, Wallerstedt S. Paracetamol medication and alcohol abuse: a dangerous combination for the liver and kidney. Scand J Gastroenterol 1987; 22: 701-704. 
10 McClain CJ, Holtzman JL, Allen J, et al. Clinical features of acetaminophen toxicity. J Clin Gastroenterol 1988; 10: 76-80.

11 Foust RT, Reddy KR, Jeffers LJ, et al. Nyquil-associated liver injury. Am J Gastroenterol 1989; 84: 422-425.

12 Shimizu M, Tokita H, Koshino Y, et al. An autopsy case of acute hepatic failure caused by ingesting a small dose of acetaminophen in a drinker. Acta Hepatologica Japonica 1989; 30: 690-694.

13 McClements BM, Hyland M, Callender ME, et al. Management of paracetamol poisoning complicated by enzyme induction due to alcohol or drugs. Lancet 1990; 335: 1526.

14 Mrvos R, Schneider SM, Dean BS, et al. Orthotopic liver transplants necessitated by acetaminophen- induced hepatotoxicity. Vet Hum Toxicol 1992; 34: 425-427.

15 Coirault C, Berton C, Tritsch L, et al. Intoxication aiguë par le paracétamol: l'administration précoce de $\mathrm{N}$-acétylcystéine réduit les risques d'hépatotoxicité. Revue Du Praticien Médecine Générale 1993; 7: 35-38.

16 Cheung L, Potts RG, Meyer KC. Acetaminophen treatment nomogram. N Engl J Med 1994; 330: 1907-1908.

17 Whitcomb DC, Block GD. Association of acetaminophen hepatotoxicity with fasting and ethanol use. JAMA 1994; 272: 1845-1850.

18 Schiødt FV, Rochling FA, Casey DL, et al. Acetaminophen toxicity in an urban county hospital. N Engl J Med 1997; 337: 1112-1117.

19 Artnak KE, Wilkinson SS. Fulminant hepatic failure in acute acetaminophen overdose. Dimensions Crit Care Nursing 1998; 17: 135-144.

20 Bridger S, Henderson K, Glucksman E, et al. Deaths from low dose paracetamol poisoning. Br Med J 1998; 316: 1724-1725.

21 Barker JD, de Carle DJ, Anuras S. Chronic excessive acetaminophen use and liver damage. Ann Intern Med 1977; 87: 299-301.

22 Goldfinger R, Ahmed KS, Pitchumoni CS, et al. Concomitant alcohol and drug abuse enhancing acetaminophen toxicity. $\mathrm{Am}$ J Gastroenterol 1978; 70: 385-388.

23 Gerber MA, Kaufmann H, Klion F, et al. Acetaminophen associated hepatic injury. Hum Pathol 1980; 11: 37-42.

24 LaBrecque DR, Mitros FA. Increased hepatotoxicity of acetaminophen in the alcoholic. Gastroenterology 1980; 78: 1310.

25 Licht H, Seeff LB, Zimmerman HJ. Apparent potentiation of acetaminophen hepatotoxicity by alcohol. Ann Intern Med 1980; 92: 511.

26 McClain CJ, Kromhout JP, Peterson FJ, et al. Potentiation of acetaminophen hepatotoxicity by alcohol. JAMA 1980; 244: 251-253.

27 Black M, Cornell JF, Rabin L, et al. Late presentation of acetaminophen hepatotoxicity. Dig Dis Sci 1982; 27: 370-374.

28 Davis AM, Helms CM, Mitros FA, et al. Severe hepatic damage after acetaminophen use in psittacosis. JAMA 1983; 74: 349-352.

29 Levinson M. Ulcer, back pain, and jaundice in an alcoholic. Hosp Pract 1983; 18: 48N-48S.

30 Saenz de Santa Maria J, Perez Miranda M, Soria A, et al. Lesión hepática por acetaminofen: a propósito de un caso con infrecuente participación portal. Revista Clínica Española 1983; 168: $355-356$.
31 Erickson RA, Runyon BA. Acetaminophen hepatotoxicity associated with alcoholic pancreatitis. Arch Intern Med 1984; 144: 1509-1510.

32 Stolt CM, Johnsen S-A. Terapeutiskt paracetamolintag orsakade akut njurinsufficiens och leverpåverkan. Läkartidningen 1984; 81: 1313.

33 Kaysen GA, Pond SM, Roper MH, et al. Combined hepatic and renal injury in alcoholics during therapeutic use of acetaminophen. Arch Intern Med 1985; 145: 2019-2023.

34 Leist MH, Gluskin LE, Payne JA. Enhanced toxicity of acetaminophen in alcoholics: report of three cases. J Clin Gastroenterol 1985; 7: 55-59.

35 Frisinette-Fich C, Lundberg M, Sörensen J. Avslutade fasta med vin och paracetamol. Patient fick lever-och njurskada. Läkartidningen 1986; 83: 2757-2758.

36 Kartsonis A, Reddy KR, Schiff ER. Alcohol, acetaminophen, and hepatic necrosis. Ann Intern Med 1986; 105: 138-139.

37 Lesser PB, Vietti MM, Clark WD. Lethal enhancement of therapeutic doses of acetaminophen by alcohol. Dig Dis Sci 1986; 31: 103-105.

38 O'Dell JR, Zetterman RK, Burnett DA. Centrilobular hepatic fibrosis following acetaminophen-induced hepatic necrosis in an alcoholic. JAMA 1986; 255: 2636-2637.

39 Seeff LB, Cuccherini BA, Zimmerman HJ, et al. Acetaminophen hepatotoxicity in alcoholics. A therapeutic misadventure. Ann Intern Med 1986; 104: 399-404.

40 Bell H, Schjonsby H, Raknerud N. Alvorlig leverskade - etter terapeutisk dose av paracetamol. Tidsskr Nor Lageforen 1987; 107: 1037-1040.

41 Bidault I, Lagier G, Garnier R, et al. Les hépatites par toxicité subaiguë du paracétamol existent-elles? Thérapie 1987; 42: 387-388.

42 Florén C-H, Thesleff P, Nilsson A. Severe liver damage caused by therapeutic doses of acetaminophen. Acta Med Scand 1987; 222: 285-288.

43 Baeg N-J, Bodenheimer HC, Burchard K. Long-term sequellae of acetaminophen-associated fulminant hepatic failure: relevance of early histology. Am J Gastroenterol 1988; 83: 569-571.

44 Björck S, Svalander CT, Aurell M. Acute renal failure after analgesic drugs including paracetamol (acetaminophen). Nephron 1988; 49: 45-53.

45 Keaton MR. Acute renal failure in an alcoholic during therapeutic acetaminophen ingestion. South Med J 1988; 81: 1163-1166.

46 Luquel L, Azzi R, Desaint B, et al. Hépato-néphrite aiguë chez l'alcoolique après prise de paracétamol à dose thérapeutique. Presse Méd 1988; 17: 1318.

47 Pezzano M, Richard Ch, Lampl E, et al. Toxicité hépatique et rénal du paracétamol chez l'alcoolique chronique. Presse Méd 1988; 17: 21-24.

48 Wootton FT, Lee WM. Acetaminophen hepatotoxicity in the alcoholic. South Med J 1990; 83: 1047-1049.

49 Kumar S, Rex DK. Failure of physicians to recognize acetaminophen hepatotoxicity in chronic alcoholics. Arch Intern Med 1991; 151: 1189-1191.

50 Cheng L. Acetaminophen-induced hepatotoxicity in an alcoholic. Pharmacol Ther 1992; 17: 1635.

51 Edwards R, Oliphant J. Paracetamol toxicity in chronic alcohol abusers - a plea for greater consumer awareness. N Z Med J 1992; 105: 174-175. 
52 Eriksson LS, Broomé U, Kalin M, et al. Hepatotoxicity due to repeated intake of low doses of paracetamol. J Intern Med 1992; 231: 567-570.

53 Guccione JL, Zemtsov A, Cobos E, et al. Acquired purpura fulminans induced by alcohol and acetaminophen: Successful treatment with heparin and vitamin K. Arch Dermatol 1993; 129: $1267-1269$.

54 Hanson L. Acute hepatic decompensation in an alcoholic. J Tenn Med Assoc 1993; 86: 448-448.

55 Rustgi VK, Manzarbeitia C, Jonsson J, et al. Low dose acetaminophen resulting in fulminant hepatic failure. Hepatology 1993; 18: 321A.

56 Sivaloganathan K, Johnson PA, Bray GP, et al. Pericoronitis and accidental paracetamol overdose: a cautionary tale. $\mathrm{Br}$ Dental J 1993; 174: 69-71.

57 Drenth JPH, Frenken LAM, Wuis EW, et al. Acute renal failure associated with paracetamol ingestion in an alcoholic patient. Nephron 1994; 67: 483-485.

58 Collins C, Starmer GA. A review of the hepatotoxicity of paracetamol at therapeutic or near-therapeutic dose levels, with particular reference to alcohol abusers. Drug Alcohol Review 1995; 14: 63-79.

59 Schueler L, Harper JL. Acetaminophen toxicity: Report of case and review of the literature. J Oral Maxillofacial Surg 1995; 53: 1208-1212.

60 Zimmerman HJ, Maddrey WC. Acetaminophen (paracetamol) hepatotoxicity with regular intake of alcohol: analysis of instances of therapeutic misadventure. Hepatology 1995; 22: 767-773.

61 Ho TW, Lam KC. Therapeutic misadventure with paracetamol. Hong Kong Med J 1996; 2: 434-436.

62 Johnston SC, Pelletier LLJ. Enhanced hepatotoxicity of acetaminophen in the alcoholic patient. Two case reports and a review of the literature. Medicine 1997; 76: 185-191.

63 Leach M, Makris M, Gleeson DC, et al. Acute liver failure induced by alcohol and paracetamol in an HCV-infected haemophiliac. Br J Haematology 1998; 103: 891-893.

64 Andreu V, Gomez-Angelats E, Bruguera M, et al. Severe hepatitis from therapeutic doses of paracetamol in an alcoholic patient. Gastroenterol Hepatol 1999; 22: 235-237.

65 Mitchell JR, Jollow DJ, Potter WZ, et al. Acetaminophen-induced hepatic necrosis. I. Role of drug metabolism. J Pharmacol Exp Ther 1973; 187: 185-194.

66 Jollow DJ, Mitchell JR, Potter WZ, et al. Acetaminophen-induced hepatic necrosis. II. Role of covalent binding in vivo. J Pharmacol Exp Ther 1973; 187: 195-202.

67 Potter WZ, Davis DC, Mitchell JR, et al. Acetaminophen-induced hepatic necrosis. III. Cytochrome P-450-mediated covalent binding in vitro. J Pharmacol Exp Ther 1973; 187: 203-210.

68 Mitchell JR, Jollow DJ, Potter WZ, et al. Acetaminophen-induced hepatic necrosis. IV. Protective role of glutathione. J Pharmacol Exp Ther 1973; 187: 211-217.

69 Miner DJ, Kissinger PT. Evidence for the involvement of $\mathrm{N}$-acetyl-p-quinoneimine in acetaminophen metabolism. Biochem Pharmacol 1979; 28: 3285-3290.

70 Corcoran GB, Mitchell JR, Vaishnav YN, et al. Evidence that acetaminophen and $\mathrm{N}$-hydroxyacetaminophen form a common arylating intermediate, $\mathrm{N}$-acetyl- $p$ benzoquinoneimine. Mol Pharmacol 1980; 18: 536-542.
71 Thummel KE, Slattery JT, Nelson SD, et al. Effect of ethanol on hepatotoxicity of acetaminophen in mice and on reactive metabolite formation by mouse and human liver microsomes. Toxicol Appl Pharmacol 1989; 100: 391-397.

72 Teschke R, Stutz G, Strohmeyer G. Increased paracetamol-induced hepatotoxicity after chronic alcohol consumption. Biochem Biophys Res Commun 1979; 91: 368-374

73 Moldéus P, Andersson B, Norling A, et al. Effect of chronic ethanol administration on drug metabolism in isolated hepatocytes with emphasis on paracetamol activation. Biochem Pharmacol 1980; 29: 1741-1745.

74 Peterson FJ, Holloway DE, Erickson RR, et al. Ethanol induction of acetaminophen toxicity and metabolism. Life Sci 1980; 27: 1705-1711.

75 Sato C, Matsuda Y, Lieber CS. Increased hepatotoxicity of acetaminophen after chronic ethanol consumption in the rat. Gastroenterology 1981; 80: 140-148.

76 Rosen GM, Singletary WV, Rauckman EJ, et al. Acetaminophen hepatotoxicity: an alternative mechanism. Biochem Pharmacol 1983; 32: 2053-2059.

77 Walker RM, McElligott TF, Power EM, et al. Increased acetaminophen-induced hepatotoxicity after chronic ethanol consumption in mice. Toxicology 1983; 28: 193-206.

78 Altomare E, Leo MA, Lieber CS. Interaction of acute ethanol administration with acetaminophen metabolism and toxicity in rats fed alcohol chronically. Alcohol Clin Exp Res 1984; 8: 405-408.

79 Altomare E, Leo MA, Sato C, et al. Interaction of ethanol with acetaminophen metabolism in the baboon. Biochem Pharmacol 1984; 33: 2207-2212.

80 Reicks MM, Hathcock JN. Effects of dietary methionine and ethanol ingestion on acetaminophen hepatotoxicity in mice. Drug-Nutr Interact 1984; 3: 43-51.

81 Tredger JM, Smith HM, Read RB, et al. Effects of ethanol ingestion on the hepatotoxicity and metabolism of paracetamol in mice. Toxicology 1985; 36: 341-352.

82 Tredger JM, Smith HM, Read RB, et al. Effects of ethanol ingestion on the metabolism of a hepatotoxic dose of paracetamol in mice. Xenobiotica 1986; 16: 661-670.

83 Carter EA. Enhanced acetaminophen toxicity associated with prior alcohol consumption in mice: prevention by N-acetylcysteine. Alcohol 1987; 4: 69-71.

84 Reicks MM, Hathcock JN. Effects of methionine deficiency and ethanol ingestion on acetaminophen metabolism in mice. J Nutrition 1987; 117: 572-579.

85 Serrar D, Thevenin M. Toxicité du paracétamol chez la souris Swiss traitée par l'alcool éthylique en aigu ou à court terme. Revue l'Alcoolisme 1987; 32: 105-111.

86 Prasad JS, Chen N, Liu Y, et al. Effects of ethanol and inhibitors on the binding and metabolism of acetaminophen and $\mathrm{N}$-acetyl-p-benzoquinone imine by hepatic microsomes from control and ethanol-treated rats. Biochem Pharmacol 1990; 40: 1989-1995.

87 Kostrubsky VE, Wood SG, Bush MD, et al. Acute hepatotoxicity of acetaminophen in rats treated with ethanol plus isopentanol. Biochem Pharmacol 1995; 50: 1743-1748.

88 Kostrubsky VE, Szakacs JG, Jeffery EH, et al. Role of CYP3A in ethanol-mediated increases in acetaminophen hepatotoxicity. Toxicol Appl Pharmacol 1997; 143: 315-323.

89 Kostrubsky VE, Szakacs JG, Jeffery EH, et al. Protection of 
ethanol-mediated acetaminophen hepatotoxicity by triacetyloleandomycin, a specific inhibitor of CYP3A. Ann Clin Lab Sci 1997; 27: 57-62.

90 Morgan ET, Koop DR, Coon MJ. Comparison of six rabbit liver cytochrome P-450 isozymes in formation of a reactive metabolite of acetaminophen. Biochem Biophys Res Commun 1983; 112: 8-13.

91 Steele CM, Masson HA, Battershill JM, et al. Metabolic activation of paracetamol by highly purified forms of cytochrome P-450. Res Commun Chem Pathol Pharmacol 1983; 40: 109-119.

92 Coon MJ, Koop DR, Reeve LE, et al. Alcohol metabolism and toxicity: role of cytochrome P-450. Fundam Appl Toxicol 1984; 4: 134-143.

93 Black M, Raucy J. Acetaminophen, alcohol, and cytochrome P-450. Ann Intern Med 1986; 104: 427-429.

94 Coon MJ, Koop DR. Alcohol-inducible cytochrome P-450 (P-450ALC). Arch Toxicol 1987; 60: 16-21.

95 Harvison PJ, Guengerich FP, Rashed MS, et al. Cytochrome $\mathrm{P}-450$ isozyme selectivity in the oxidation of acetaminophen. Chem Res Toxicol 1988; 1: 47-52.

96 Raucy JL, Sker JML, Lieber CS, et al. Acetaminophen activation by human liver cytochromes P450IIE1 and P450IA2. Arch Biochem Biophys 1989; 271: 270-283.

97 Patten CJ, Thomas PE, Guy RL, et al. Cytochrome P450 enzymes involved in acetaminophen activation by rat and human liver microsomes and their kinetics. Chem Res Toxicol 1993; 6: 511-518.

98 Snawder JE, Benson RW, Leakey JEA, et al. The effect of propylene glycol on the P450-dependent metabolism of acetaminophen and other chemicals in subcellular fractions of mouse liver. Life Sci 1993; 52: 183-189.

99 Snawder JE, Roe AL, Benson RW, et al. Loss of CYP2E1 and CYP1A2 activity as a function of acetaminophen dose: relation to toxicity. Biochem Biophys Res Commun 1994; 203: $532-539$.

100 Thomsen MS, Loft S, Roberts DW, et al. Cytochrome P4502E1 inhibition by propylene glycol prevents acetaminophen (paracetamol) hepatotoxicity in mice without cytochrome P4501A2 inhibition. Pharmacol Toxicol 1995; 76: 395-399.

101 Lee SST, Buters JTM, Pineau T, et al. Role of CYP2E1 in the hepatotoxicity of acetaminophen. J Biol Chem 1996; 271: 12063-12067.

102 Slattery JT, Nelson SD, Thummel KE. The complex interaction between ethanol and acetaminophen. Clin Pharmacol Ther 1996; 60: 241-246.

103 Shimazaki M, Sugihara J-I, Murakami N, et al. Three cases of severe acetaminophen overdose. Acta Hepatologica Japonica 1989; 30: 1520-1525.

104 Krenzelok EP, Best L, Manoguerra AS. Acetaminophen toxicity. Am J Hosp Pharm 1977; 34: 391-394.

105 Zabrodski RM, Schnurr LP. Anion gap acidosis with hypoglycemia in acetaminophen toxicity. Arch Emerg Med 1984; 13: 956-959.

106 Read RB, Tredger JM, Williams R. Analysis of factors responsible for continuing mortality after paracetamol overdose. Hum Toxicol 1986; 5: 201-206.

107 Brotodihardjo AE, Batey RG, Farrell GC, et al. Hepatotoxicity from paracetamol self-poisoning in western Sydney: a continuing challenge. Med J Aust 1992; 157: 382-385.
108 Makin AJ, Wendon J, Williams R. A seven year experience of severe acetaminophen-induced hepatotoxicity (1987-93). Gastroenterology 1995; 109: 1907-1916.

109 Bradley MP, Nguyen-Van-Tam JS, Pearson JCG. 'Late presenter' after paracetamol self-poisoning. J Epidemiol Community Health 1998; 52: 762-763.

110 Bray GP, Mowat C, Muir DF, et al. The effect of chronic alcohol intake on prognosis and outcome in paracetamol overdose. Hum Exp Toxicol 1991; 10: 435-438.

111 Rumack BH, Peterson RG, Koch GC, et al. Acetaminophen overdose. 662 cases with evaluation of oral acetylcysteine treatment. Arch Intern Med 1981; 141: 380-385.

112 Rumack BH. Acetaminophen overdose. Am J Med 1983; 75(Suppl5A): 104-112.

113 Smilkstein MJ, Knapp GL, Kulig KW, et al. Efficacy of oral $\mathrm{N}$-acetylcysteine in the treatment of acetaminophen overdose: analysis of the national multicenter study (1976-85). N Engl J Med 1988; 319: 1557-1562.

114 Smilkstein MJ, Bronstein AC, Linden C, et al. Acetaminophen overdose: a 48-hour intravenous $\mathrm{N}$-acetylcysteine treatment protocol. Ann Emerg Med 1991; 20: 1058-1063.

115 Smilkstein MJ, Rumack BH. Chronic ethanol use and acute acetaminophen overdose toxicity. J Toxicol Clin Toxicol 1998; 36: 476.

116 Price VF, Miller MG, Jollow DJ. Mechanisms of fasting-induced potentiation of acetaminophen hepatotoxicity in the rat. Biochem Pharmacol 1987; 36: 427-433.

117 Smilkstein MJ, Douglas DR, Daya MR. Acetaminophen poisoning and liver function. N Engl J Med 1994; 331: 1310-1311.

118 Denison H, Kaczynski J, Wallerstedt S. Paracetamol i terapeutiska doser kan ge svara lever-och njurskador hos alkoholister. Läkartidningen 1991; 88: 2664-2665.

119 Black M. Acetaminophen hepatotoxicity. Ann Rev Med 1984; 35: 577-593.

120 Seifert CF, Lucas DS, Vondracek TG, et al. Patterns of acetaminophen use in alcoholic patients. Pharmacotherapy 1993; 13: 391-395.

121 Mitchell JR, Thorgeirsson SS, Potter WZ, et al. Acetaminophen-induced hepatic injury: protective role of glutathione in man and rationale for therapy. Clin Pharmacol Ther 1974; 16: 676-684.

122 Prescott LF. Paracetamol overdosage: pharmacological considerations and clinical management. Drugs 1983; 25: 290-314

123 Grinblat J, Lewitus Z, Rosenfeld J. Renal tubular necrosis and liver damage. A possible consequence of low dose of acetaminophen and halothane anesthesia. Drug Intelligence Clin Pharm 1980; 14: 431-435.

124 Pirotte JH. Apparent potentiation by phenobarbital of hepatotoxicity from small doses of acetaminophen. Ann Intern Med 1984; 101: 403.

125 Patel F. The fatal paracetamol dosage - how low can you go? Med Sci Law 1992; 32: 303-310.

126 Crippin JS. Acetaminophen hepatotoxicity: potentiation by isoniazid. Am J Gastroenterol 1993; 88: 590-592.

127 Nolan CM, Sandblom RE, Thummel KE, et al Hepatotoxicity associated with acetaminophen usage in 
patients receiving multiple drug therapy for tuberculosis. Chest 1994; 105: 408-411.

128 Tredger JM, Thuluvath P, Williams R, et al. Metabolic basis for high paracetamol dosage without hepatic injury: a case study. Hum Exp Toxicol 1995; 14: 8-12.

129 Wong LT, Whitehouse LW, Solomonraj G, et al. Effect of a concomitant single dose of ethanol on the hepatotoxicity and metabolism of acetaminophen in mice. Toxicology 1980; 17: 297-309.

130 Sato C, Nakano M, Lieber CS. Prevention of acetaminophen-induced hepatotoxicity by acute ethanol administration in the rat: comparison with carbon tetrachloride-induced hepatotoxicity. J Pharmacol Exp Ther 1981; 218: 805-810.

131 Banda PW, Quart BD. The effect of alcohol on the toxicity of acetaminophen in mice. Res Commun Chem Pathol Pharmacol 1984; 43: 127-138.

132 Garrido A, Fairlie J, Guerra R, et al. The flavonoid silybin ameliorates the protective effect of ethanol on acetaminophen hepatotoxicity. Res Comm Subst Abuse 1989; 10: 193-196.

133 Kröger H, Klewer M, Grätz R, et al. The influence of diet free of NAD-precursors on acetaminophen hepatotoxicity in mice. Gen Pharmacol 1996; 27: 79-82.

134 Lee S-M, Cho T-S, Cha Y-N. Ethanol prevents from acetaminophen inducible hepatic necrosis by inhibiting its metabolic activation in mice. Korean J Physiol Pharmacol 1998; 2: 261-269.

135 Sato C, Lieber CS. Mechanism of the preventive effect of ethanol on acetaminophen-induced hepatotoxicity.

J Pharmacol Exp Ther 1981; 218: 811-815.

136 Thummel KE, Slattery JT, Nelson SD. Mechanism by which ethanol diminishes the hepatotoxicity of acetaminophen. J Pharmacol Exp Ther 1988; 245: 129-136.

137 Sato C, Liu J, Miyakawa H, et al. Inhibition of acetaminophen activation by ethanol and acetaldehyde in liver microsomes. Life Sci 1991; 49: 1787-1791.

138 Strubelt O, Obermeier F, Siegers C-P. The influence of ethanol pretreatment on the effects of nine hepatotoxic agents. Acta Pharmacol Toxicol 1978; 43: 211-218.

139 Jaya DS, Augstine J, Menon VP. Role of lipid peroxides, glutathione and antiperoxidative enzymes in alcohol and drug toxicity. Indian J Exp Biol 1993; 31: 453-459.

140 Jaya DS, Augstine J, Menon VP. Protective role of $\mathrm{N}$-acetylcysteine against alcohol and paracetamol induced toxicity. Indian J Clin Biochem 1994; 9: 64-71.

141 Jaya DS, Augstine J, Menon VP. Protective effect of testosterone against alcohol and paracetamol induced hepatotoxicity in rats. Indian J Exp Biol 1995; 33: 194-200.

142 Wang P-Y, Kaneko T, Wang Y, et al. Acarbose alone or in combination with ethanol potentiates the hepatotoxicity of carbon tetrachloride and acetaminophen in rats. Hepatology 1999; 29: 161-165.

143 Vendemiale G, Altomare E, Lieber CS. Altered biliary excretion of acetaminophen in rats fed ethanol chronically. Drug Metab Dispos 1984; 12: 20-24.

144 Banda PW, Quart BD. The effect of mild alcohol consumption on the metabolism of acetaminophen in man. Res Commun Chem Pathol Pharmacol 1982; 38: 57-70.

145 Critchley JAJH, Dyson EH, Scott AW, et al. Is there a place for cimetidine or ethanol in the treatment of paracetamol poisoning? Lancet 1983; i: 1375-1376.
146 Altomare E, Vendemiale G, Trizio T, et al. Does acute ethanol really protect against acetaminophen hepatotoxicity? Am J Gastroenterol 1986; 81: 91-93.

147 Chien JY, Thummel KE, Slattery JT, et al. Ethanol increases risk of acetaminophen hepatotoxicity in adults. Hepatology 1998; 28: 257A.

148 Prescott LF, Critchley JAJH. Drug interactions affecting analgesic toxicity. Am J Med 1983; 75 (Suppl. 5A): 113-116.

149 National Poisons Information Service Monitoring Group. Analgesic poisoning: a multi-centre, prospective survey. Hum Toxicol 1981; 1: 7-23.

150 Rumack BH. Acetaminophen overdose in young children: Treatment and effects of alcohol and other additional ingestants in 417 cases. Am J Dis Child 1984; 138: 428-433.

151 Perrot N, Nalpas B, Yang CS, et al. Modulation of cytochrome P450 isozymes in human liver, by ethanol and drug intake. Eur J Clin Invest 1989; 19: 549-555.

152 Kostrubsky VE, Strom SC, Wood SG, et al. Ethanol and isopentanol increase CYP3A and CYP2E in primary cultures of human hepatocytes. Arch Biochem Biophys 1995; 322: 516-520.

153 Hoensch HP. Enzyminduktion der Leber durch chronischen Alkoholismus als Risikofaktor der Hepatotoxizität. $Z$ Gastroenterol 1984; 22: 1-8.

154 Girre C, Lucas D, Hispard E, et al. Assessment of cytochrome P4502E1 induction in alcoholic patients by chlorzoxazone pharmacokinetics. Biochem Pharmacol 1994; 47: 1503-1508.

155 Dilger K, Metzler J, Bode JC, et al. CYP2E1 activity in patients with alcoholic liver disease. J Hepatol 1997; 27: 1009-1014.

156 Lucas D, Ménez C, Girre C, et al. Decrease in cytochrome $\mathrm{P} 4502 \mathrm{E} 1$ as assessed by the rate of chlorzoxazone hydroxylation in alcoholics during the withdrawal phase. Alcohol Clin Exp Res 1995; 19: 362-366.

157 Klotz U, Ammon E. Clinical and toxicological consequences of the inductive potential of ethanol. Eur J Clin Pharmacol 1998; 54: 7-12.

158 Kuffner E, Bogdan GM, Dart RC. Evaluation of hepatotoxicity in alcoholics from therapeutic dosing of acetaminophen. J Toxicol Clin Toxicol 1997; 35: 561.

159 Kenny JF, Pollack M, Rothman R, et al. Routine screening for acetaminophen (APAP) toxicity of patients requesting alcohol detoxification. J Studies Alcohol 1999; 60: 139-140.

160 Villeneuve J-P, Raymond G, Bruneau J, et al. Pharmacocinétique et métabolisme de l'acétaminophène chez des sujets normaux, alcooliques et cirrhotiques. Gastroenterol Clin Biol 1983; 7: 898-902.

161 Chern I, Brent J, Slattery J, et al. Is it safe to give acetaminophen to alcoholics? A metabolic study. Vet Hum Toxicol 1993; 35: 365.

162 Lauterburg BH, Velez ME. Glutathione deficiency in alcoholics: risk factor for paracetamol heptotoxicity. Gut 1988; 29: 1153-1157.

163 Skinner MH, Matano R, Hazle W, et al. Acetaminophen metabolism in recovering alcoholics. Meth Find Exp Clin Pharmacol 1990; 12: 513-515.

164 Dietz AJ, Carlson JD, Wahba Khalil SK, et al. Effects of alcoholism on acetaminophen pharmacokinetics in man.J Clin Pharmacol 1984; 24: 205-208.

165 Girre C, Hispard E, Palombo S, et al. Increased metabolism of 
acetaminophen in chronically alcoholic patients. Alcohol Clin Exp Res 1993; 17: 170-173.

166 Ueshima Y, Tsutsumi M, Takase S, et al. Acetaminophen metabolism in patients with different cytochrome P-4502E1 genotypes. Alcohol Clin Exp Res 1996; 20: 25A-28A.

167 Lauterburg BH, Davies S, Mitchell JR. Ethanol suppresses hepatic glutathione synthesis in rats in vivo. J Pharmacol Exp Ther 1984; 230: 7-11.

168 Sinclair J, Jeffery E, Wrighton S, et al. Alcohol-mediated increases in acetaminophen hepatotoxicity: role of CYP2E and CYP3A. Biochem Pharmacol 1998; 55: 1557-1565.

169 Chen W, Koenigs LL, Thompson SJ, et al. Oxidation of acetaminophen to its toxic quinone imine and nontoxic catechol metabolites by baculovirus-expressed and purified human cytochromes P450 2E1 and 2A6. Chem Res Toxicol 1998; 11: 295-301.
170 Thummel KE, Lee CA, Kunze KL, et al. Oxidation of acetaminophen to $N$-acetyl- $p$-aminobenzoquinone imine by human CYP3A4. Biochem Pharmacol 1993; 45: 1563-1569.

171 Lee CA, Thummel KE, Kalhorn TF, et al. Inhibition and activation of acetaminophen reactive metabolite formation by caffeine: Roles of cytochromes P-450IA1 and IIIA2. Drug Metabolism Disposition 1991; 19: 348-353.

172 Zaher H, Buters JT, Ward JM, et al. Protection against acetaminophen toxicity in CYP1A2 and CYP2E1 double-null mice. Toxicol Appl Pharmacol 1998; 152: 193-199.

173 Sarich T, Kalhorn T, Magee S, et al. The effect of omeprazole pretreatment on acetaminophen metabolism in rapid and slow metabolizers of $S$-mephenytoin. Clin Pharmacol Ther 1997; 62: 21-28. 